\title{
The Impact of the Underground Economy on American Business
}

\author{
John O. King \\ Department of Marketing \\ and \\ Joseph H. Miller \\ College of Business \\ Southeastern Louisiana University \\ Hammond, Louisiana
}

\section{Introduction}

The underground economy refers to activities giving rise to unreported, unmeasured and untaxed income, whether earned from legal or illegal sources (5). The underground economy has many different names - in Britain it is called the black economy, in Germany the shadow economy, and in Italy it is referred to as the submerged economy. Bookmaking, prostitution, smuggling, and illegal drugs are some of the activities of the underground economy. Business activities which are legal and desirable fall into the underground economy when the business people involved choose to cover up part or all of the income from these activities. A business owner who doesn't ring up all cash sales, the plumber who works for cash only, and the teacher who gives the beautician a music lesson in exchange for a haircut, are all examples of the underground economy. The income earned in the underground economy is usually referred to as 'off-the-books' income. If this income were reported it would add to the GNP.

The purposes of this paper are to describe the size of the underground economy, identify those factors that have caused the underground economy to flourish and to examine the effect that the underground economy has had on the business practices. Both the ethical and economic impact of the underground economy are examined.

Dr. Edgar Feige of the University of Wisconsin estimates that the unreported income from the underground economy is as high as 27 percent of our GNP (3). In terms of the 1986 economy, this would mean an underground economy in the vicinity of $\$ 1$ trillion. Research at the Federal Reserve Bank of Atlanta concluded that the underground economy grew from 9 percent of reported GNP in 1970 to at least 15 percent of GNP in 1978 (5). In 1977, Professor Peter Gutmann of Baruch College estimated the underground economy at 10 percent of the recorded GNP (4). While estimates by Gutmann assume that all hidden transactions are done with cash, Feige's estimate of 27 percent uses additional methods of payment, such as checks. However, 
none of the estimates take into consideration unreported barter-the practice of exchanging one service or product for another (1).

The first in-depth effort by the IRS to measure unreported individual income uses 1976 tax-year data (2). This study reported that individuals failed to declare $\$ 75-\$ 100$ billion in legal income that year, resulting in a loss of $\$ 13-\$ 17$ billion in tax revenue. The greater part of business activity covered in the IRS study was legal, but the participating individuals illegally failed to report the generated income. The same study estimated that unreported income from illicit trade costs the government some $\$ 6-\$ 9$ billion in lost tax revenues annually. However, as increasingly larger caches of illegal drugs are discovered, this amount may be understated. One bank in Florida reports receiving $\$ 1.2$ million in $\$ 20, \$ 50$, and $\$ 100$ bills in one afternoon and more than $\$ 10$ million in currency in one week, all from illegal cash transactions of its depositors (9). Another bank in California reported its employees as 'almost suffering hernias' from having to carry in so many boxes of currency from a dope-dealing depositor (10). Such efforts on the part of the underworld to 'launder' money have become commonplace.

While no one can be sure of the exact size of the underground economy, it is certain that it is growing at a faster rate than the above ground economy. Using an econometric model, Professor Feige estimated that during the 1970's the underground economy increased at $21 / 2$ times the rate of the above ground economy (15).

Probably the most serious threat posed by the underground economy directly on legitimate American businesses is in the area of illegally counterfeited products. The true extent of this aspect of the underground economy cannot be measured, but The Counterfeit Intelligence Bureau in London estimates that up to $\$ 60$ billion in annual world trade involved counterfeit products in 1985. The United States House of Representatives' Energy and Commerce Committee recently estimated direct losses for American firms to counterfeit products at approximately $\$ 20$ billion annually. Not only does product counterfeiting involve such consumer goods as Cartier watches and Cabbage Patch Dolls, but also chemicals, drugs, pesticides, military hardware, food, and thousands of replacement and component parts. The impact of counterfeit goods on one American based multinational corporation is shown by General Motors' estimate that nearly 40 percent of all GM parts in the Middle East are counterfeit (10).

There are many factors that have caused the underground economy to flourish at an ever increasing rate. One such factor is the overall increase in criminal activity in recent decades, especially drug and narcotic trafficking. In addition to this, high income tax rates, overall inflation, and a distrust of government at all levels have caused many average citizens to explore the possibility of operating in the underground economy. Because of actual and potential economic benefits, operating in the underground economy tends to be habit forming for the individuals directly involved, and it tends to spread like a communicable disease as others in society observe the apparent 
economic rewards accruing to those operating in the underground economy. In fact, because of the perceived low probability of legal punishment, the major deterrent for most individuals is their particular moral and ethical convictions. One measure of the level of these convictions is seen in the results of two recent surveys concerning cheating on income taxes. A 1984 poll commissioned anonymously by the Internal Revenue Service found 19 percent of the respondents admitted being less than completely honest on their tax returns. A similar poll completed for U.S. News and World Report in 1985 found 24 percent of the respondents admitted to dishonesty when filing federal income taxes (7).

\section{Business Implications}

From the business point of view, it is useful to separate the underground economy into two large segments based on the legal dimensions of the activities. First, we have those economic activities that are illegal for all persons engaged in the production or marketing of the good or service. In this group we find businesses actively engaged in the drug market, trafficking in stolen goods, producing counterfeit goods and smuggling. For reference purposes, we have chosen to designate these as Class I activities. Again, readers are reminded that Class I activities are all in violation of various local, state or federal laws.

The second major segment of the underground economy is composed of legal economic activities, but which become illegal because of the way some dimension of the activity is handled. For example, hiring a carpenter to install storm windows on a house is a perfectly legal activity and paying him in cash is equally legal. However, if he fails to report this cash as income he is in violation of federal income tax laws. In this paper, all such activities are classified as Class II activities.

\section{Class I Activities}

Businesses should never be involved in Class I activities because they are illegal. However, such illegal economic activities are of major concern to business managers because of the following reasons:

1. Smuggled, stolen and counterfeit goods are sold in the market in competition with ordinary goods which tends to give their marketers an unfair cost profit/advantage.

2. Huge potential tax revenues are lost in the Class I segment of the economy. These are tax revenues that will have to be ultimately paid by the above ground segment of the economy.

3. Efforts to police and punish offenders in the Class I segment of the economy represents a major drain on governmental budgets at all levels of government. This is money that could and should be spent on more socially desirable projects. 
4. The Class I underground economy tends to have a corrupting influence on governmental officials through attempted bribery and political contributions; thus, lowering the overall efficiency of government.

5. Consumer expenditures for illegal goods and services represent lost sales for the legitimate businesses of government.

These Class I aspects of the underground economy represent a major component of what has been called an 'unwholesome demand' (6). In such situations, the primary goal of the ethical business organization is to unsell the target market on the goods and services involved. Unselling a market tends to be very slow, expensive and difficult because it often represents an attempt at intervening in the ways people think and behave. The time, difficulty, and expense associated with unselling a target market or the elimination of the 'unwholesome demand' helps explain why it tends to be most often attempted by large corporations, trade associations, nonprofit organizations and governments.

It is obviously desirable for businesses to be informed on the nature and extent of the Class I segment of the underground economy. This is especially true when the illegal activity represents direct or indirect competition for their lines of business. Also, because of the probable inferior quality and performance of most counterfeit goods, business firms must be on the alert to take legal action against all types of offenders, as well as being ready to defend against product liability suits growing out of consumer injury from the use of counterfeit products and replacement parts.

\section{Class II Activities}

Business interest in the Class II segment of the underground economy stems from many of the same reasons as does their interest in the Class I activities. Namely, the unfair competitive element, lost tax revenues for governments, and social costs associated with legal enforcement. In addition, there is an ethical dimension when a marketer has reason to believe that one or more of his business contacts is operating in the Class II underground economy. For example, if a supplier of goods or services requests payment in cash, should the buyer report such a transaction to tax authorities on the presumption that the recipient does not plan to report the cash received as income? Obviously, the answer to such ethical questions will depend upon the ethical standards of the persons involved.

Businesses that contend that they know very little about the underground economy surrounding their lines of business may be telling the truth, but if so, they are probably equally uninformed about the above ground economy in which they operate. For example, a good sales analysis will tell a business who is buying, what they are buying, how they are paying, who is making the sales, and how the goods are being shipped, such that an alert business will have a pretty good idea of the extent of his intentional and accidental involvement in the underground economy. What is really being said is that the 
extent of a firm's involvement in the underground economy is very dependent on the ethical values of the management personnel in the firm.

\section{Impact on Business Planning}

\section{Use of Incorrect Data}

Businesses who engage in strategic planning rely heavily on data from both public and private sources. It is a certainty that omission of data on the underground economy causes many economic indicators to understate the health of the U.S. economy and its various segments. It is widely believed that unemployment figures are too high and personal savings too low. Peter Gutmann of Baruch College maintains that the underground economy causes the true unemployment rate to be overstated by two percentage points, or about 2 million people (15). In recent years, economic statistics have indicated that personal savings have been decreasing. Because of the increased activity in the underground economy, many economists and business planners believe that the Commerce Department's personal savings estimates are incorrect. Further proof of the magnitude of this problem is seen by observing that at a given time the flow of funds data from the Federal Reserve showed the savings rate could actually be as high as 9.4 percent at the time the Department of Commerce was estimating it to be 5.3 percent of disposable income. This translates into a difference of approximately $\$ 75$ billion in savings.

The use of incorrect economic data will certainly impact business planning. High unemployment and low personal savings data will cause businesses to be too conservative in their forecasting. In general, businesses may have held off on expansion-both in the purchase of capital equipment and in the addition of new product lines as a result of erroneous data which did not consider the operations of the underground economy.

\section{Human Resource Planning}

The underground economy is even thought to be having a major impact in the area of human resource planning. Consider that in 1980 the level of total employment rose by only 0.3 percent, but the number of self-employed rose by 3 percent to a new high of 6.9 million. In the decade of the 1970 's, the number of self-employed increased 30 percent faster than did total employment (15). Large business corporations appear to be suffering most from this move to become self-employed as increasing numbers of highly skilled personnel have left after the corporation had invested heavily in developing their various abilities. While no data appears to be available on the true extent of talented people moving into the underground economy, the mere fact that the underground economy exists and is growing rapidly among self-employed people leads the authors to believe that many of these talented people are contributing to the growth of the underground economy.

\section{Summary and Conclusions}

Existing environmental factors indicate that the underground economy will continue te grow at a faster rate than the above ground economy. In- 
creases in the level of criminal activity, high taxes, inflation, changing moral values, and a general distrust of government all point toward this trend. The total business implications of the underground economy are numerous, complicated and varied. When analyzing the underground economy it is useful to divide it into two broad segments. The first segment, which we have designated as the Class I segment, is composed of business activities that are illegal in all respects and should never be practiced. The second major segment of the underground economy has been designated the Class II segment and refers to those business activities that are not inherently illegal, but certain aspects of these business activities become illegal when practiced in an illegal way.

The underground economy has caused many businesses to offer a dual pricing structure rewarding customers with special discounts if they pay cash instead of using checks or credit cards. It has also fostered increases in bartering among both households and businesses, and may be contributing toward the growing level of self-employment; particularly in markets where it is relatively easy for the business person to conceal profits.

Changing moral and ethical values of our society coupled with the inability of legal authorities to enforce laws governing activities involved in the underground economy also point toward the continued rapid growth of this segment of the American economy. In fact, unless the non-participants in the underground economy become concerned to the point of drastic political or legal action, the underground economy will eventually become so large as to seriously cripple the health and efficiency of the above ground economy.

\section{References}

1. Batt, William. "The Underground Economy: What Is It? How Big Is It? and How Is It Measured?" Manhattan College Journal of Business Fall, 1985, pp. 5-10.

2. "Estimates of Income Unreported on Individual Income Tax Returns," Department of the Treasury, Internal Revenue Service, Publication 1104, pp. 9-79.

3. Feige, Edgar. "The Irregular Economy: Its Size and Macroeconomic Implications," Working Paper 7916, Social System Research Institute.

4. Gutmann, Peter. "The Subterranean Economy," Financial Analysts Journal, November-December, 1977, pp. 23-26.

5. Haulk, Charles, J. "Thoughts on the Underground Economy," Economic Review of the Federal Reserve Bank of Atlanta March-April, 1980, pp. 23-24.

6. Kotler, Philip. "The Major Tasks of Marketing Management," Journal of Marketing, October, 1973, pp. 41-49. 
7. McBee, Susanna. "Morality," U.S. News \& World Report, December 9, 1985, pp. 52-58.

8. Molefsky, Barry. "The Underground Economy in the United States and Abroad," Conference Board, Federal Reserve System.

9. Montgomery, Jim. "Feds Crack Down on 'Laundering' of Narcotics Money," The Wall Street Journal, March 12, 1981, p.1.

10. O'Donnell, Thomas C., et al, "The Counterfeit Trade," Business Week, December 16, 1985, pp. 64-72.

11. Penn, Stanley, "Narcotics Agents Track Big Cash Transactions to Trap Dope Dealers," The Wall Street Journal, November 2226, 1980, p.1.

12. Powell, Eileen A. "IRS Chief Lists Achievements as He Departs," The Wall Street Journal, November 5, 1980, p. 27.

13. Simon, Carl P. and Ann D. Witte, Beating the System, Chicago: Auburn Press, 1982.

14. "The Income Farmers Hide," Business Week, April 17, 1978, pp. 91-92.

15. "The Underground Economy's Hidden Force," Business Week, April 5, 1982, pp. 64-70.

16. "The Underground Economy's Hidden Force," The Wall Street Journal, January 21, 1981, p.1.

17. "Underground Economy: $\$ 100$ Billion in Lost Taxes," U.S. News \& World Report, April 19, 1982, pp. 48-49. 